[Agr. Biol. Chem., Vol. 29, No. 7, p. 621 625, 1965]

\title{
Contribution of Glucose Phosphorylation to Glucose Metabolism in Brevibacterium fuscum
}

\author{
By Narimasa SAIto \\ Noda Institute for Scientific Research, Noda-shi, Chiba-ken, Japan \\ Received January 11, 1965
}

\begin{abstract}
When the 'dihydroxyacetone-fermentation' was carried out in a steady state by the cells of $\mathrm{Br}$. fuscum, it was suggested that the consumption rate of glucose in the medium might be regulated at the initial stages of glucose degradation such as; (a) glucose isomerization, (b) glucose dehydrogenation, and (c) glucose phosphorylation. Of these three enzymatic reactions, the isomerization and the dehydrogenation were proved to be unable to occur or negligible in vivo. So, in consideration of the pool sizes of $\mathrm{Mg}^{++}, \mathrm{Pi}^{+} \mathrm{H}^{+}$, glucose, G6P*, ATP, ADP, etc., the intracellular glucokinase** activity was calculated. Results indicate that glucokinase reaction may be the limiting factor for direct glucose metabolism in Br. fuscum.
\end{abstract}

\section{INTRODUCTION}

In the course of the works on the sugar metabolism in bacteria, a strain of Br. fuscum was found to metabolize glucose to DHA, etc. ${ }^{1)}$ Furthermore, from the quantitative analysis of intracellular glycolytic intermediates, it was revealed that gulcose was in the highest level in the cells harvested after twenty-two hr's cultivation. ${ }^{2}$ Although the rate of glucose utilization was found to be influenced by environmental factors, a preliminary test suggested that the DHA-fermentation in resting cells proceeds at a steady state.

In the previous paper, the purification and the properties of glucokinase in this organism were reported, and some works of kinetics of the reactions also studied. ${ }^{31}$ This paper describes the relations between extracellular rate of glcose consumption and intracellular levels of the enzymes such as glucokinase, glucose

\footnotetext{
* Abbreviations used in this work: G6P, glucose 6-phos phate; DHA, dibydroxyacetone; TCA, trichloroacetic acid; TTC, 2, 3, 5 triphenyl tetrazolium chloride.

** ATP: D-glucose 6-phosphotransferase (EC 2.7.1.2).

1) N. Saito and S. Sugiyama, This Journal, 28, 48 (1964).

2) N. Saito, J. Biochem., 57, 7 (1965).

3) N. Saito, I. Biochem., 57, 363 (1965).
}

dehydrogenase ${ }^{* * *}$ and glucose isomerase ${ }^{* * *}$, when the DHA fermentation was carring out in the steady state.

\section{EXPERIMENTALS}

Materials Commercially available chemicals were used.

Cultivation of Bacteria $\mathrm{Br}$. fuscum was cultivated at $30^{\circ} \mathrm{C}$ in the $5 \%$ glucose medium as reported in the previous paper. ${ }^{1}$

After sixteen hr. multiplication of the cells was stopped. The broth cultured for twenty-two hr. was cooled to $2^{\circ} \mathrm{C}$ promptly, and then the cells were harvested by centrifugation at $2^{\circ} \mathrm{C}$ and washed three times with cold $0.05 \mathrm{M}$ Tris buffer, $\mathrm{pH} 7.2$.

Preparation of Glucose-Free Resting Cells in order to assay for glucose dehydrogenase activity of intact cells, the cells were suspended in a sufficient

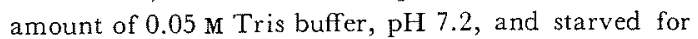
thirty hr. at $30^{\circ} \mathrm{C}$ under shaking, because the washed cells were found to keep still some amounts of glucose in the cytoplasm. The starved cells were collected and washed three times with the cold buffer. Finally, the cells were suspended in distilled water of 4 -fold weight of the wet cells.

Determinations All spectrophotometric measurements were carried out with a Klett-Summerson $\begin{array}{cl}{ }^{* * *} & \beta-\mathrm{D} \cdot \mathrm{glu} \text { cose: } \mathrm{NAD}(\mathrm{P}) \text { oxidoreductase (EC 1.1.1.47). } \\ * * * * * & \text { D-glucose ketol-isomerase (EC 5.1.3. group). }\end{array}$ 
photoelectric colorimeter.

DHA and ketohexose were determined at the same time by the method of Dische and Borenfreund ${ }^{4}$ after deproteinization with $5 \%$ zinc sulfate and $0.3 \mathrm{~N}$ barium hydroxide.

After separation of sugars using strong base anion resin, 5) the effluent fractions were analyzed by the quantitative anthrone method of Scott and Melvin's) for hexose, and the Bial reaction of Miller et al.7) for ketopentose.

Glucokinase Activity The assay of glucokinase was made as previously described. ${ }^{3}$

Assay of Glucose Dehydrogenase Activity The assay of glucose dehydrogenase was carried out according to the method of Brodie and Gots ${ }^{8}$ using TTC. The assay mixture contained $10 \mu$ moles of D-glucose, $75 \mu$ moles of Tris buffer, $\mathrm{pH} 8.0,1.0$ $\mu$ molse of TTC and the suspension of glucose-free resting cells prepared as mentioned above in a final volume of $3.0 \mathrm{ml}$. Incubation was carried out for five minutes at $22^{\circ} \mathrm{C}$, then the reaction was terminated by adding $2 \mathrm{ml}$ of $20 \%$ TCA. The coloring product was extracted with $5.0 \mathrm{ml}$ of ethylacetate and then the absorption spectra at $470 \mathrm{~m} \mu$ were estimated.

Assay of Glucose Isomerase Activity Glucose isomerase activity was estimated by the method of Takasaki and Tanabe's) using cell suspension or cellfree extract. The composition of the reaction mixture was $1.0 \mathrm{ml}$ of $0.05 \mathrm{M}$ sodium borate- $0.1 \mathrm{M}$ potassium phosphate buffer $(\mathrm{pH} 7.7), 0.1 \mathrm{ml}$ of $0.1 \mathrm{M}$ glucose and $0.5 \mathrm{ml}$ of cell suspension or its sonic extract in a total volume of $2.0 \mathrm{ml}$. The mixture was incubated for ten to forty minutes, and then the reaction was terminated by the addition of $2.0 \mathrm{ml}$ of $0.5 \mathrm{M}$ $\mathrm{HClO}_{4}$. After centrifugation, the supernatant fluid was analyzed by the quantitative cysteine-carbazol method for fructose. The optical density was recorded at $560 \mathrm{~m} \mu$ against control containing all the components of the reaction except glucose.

\section{RESULTS AND DISCUSSION}

\section{I) Velocity of Glucose Disappearance and of}

4) Z. Dische and E. Borenfreund, J. Biol. Chem., 192, 583 (1951).

5) J. X. Khym and L.P. Zill, J. Am. Chem. Soc, 75, 1339 (1953).

6) T. A. Scott and Jr. E.H. Melvin, Anal. Chem., 25, 1656 (1953).

7) G. L. Miller, R. H. Golder and E. E. Miller, Anal. Chem., 23, 903 (1951).

8) A. F. Brodi. and J.S. Gots, Science, 116, 588 (1952)

9) Y. Takasaki and O. Tanabe, J. Agr. Chem. Soc. Japan, 36, 1010 (1962).
Ketose Formation in the Course of Incubation using Resting Cells The washed cells were suspended in a following $0.3 \%$ glucose-inorganic salts medium $\left(1 \times 10^{9}\right.$ cells $\left./ \mathrm{ml}\right)$ and incubated at $30^{\circ} \mathrm{C}$. The composition of the incubation mixture was $1.67 \times 10^{-2} \mathrm{M}$ glucose, $1 \times 10^{-2} \mathrm{M}$ Tris buffer $(\mathrm{pH} \quad 8.0), \quad 7.7 \times 10^{-4} \mathrm{M}$ potassium biphosphate, $2 \times 10^{-4} \mathrm{M}$ magnesium sulfate and $0.33 \mathrm{~g}$ (as dry weight) of resting cells in a total volume of $100 \mathrm{ml}$. Velocities of glucose consumpion and DHA formation were checked.

It was revealed that the rate of glucose consumption was nearly 5 times as much as that of DHA formation as shown in Fig. 1. On the basis of these data, the rate of glucose consumption was calculated to be $3.96 \mathrm{~g}$ per hr. per $100 \mathrm{~g}$ of the cells (as wet weight), while that of DHA accumulation $0.73 \mathrm{~g}$ per hr. per $100 \mathrm{~g}$ of the wet cells. These values bore close resemblances to those obtained after twenty two hr. in the case of growing culture with $5 \%$ glucose medium at $30^{\circ} \mathrm{C}$.

As for other ketoses except DHA, only a small amount of ketohexose was formed (Fig. 1).

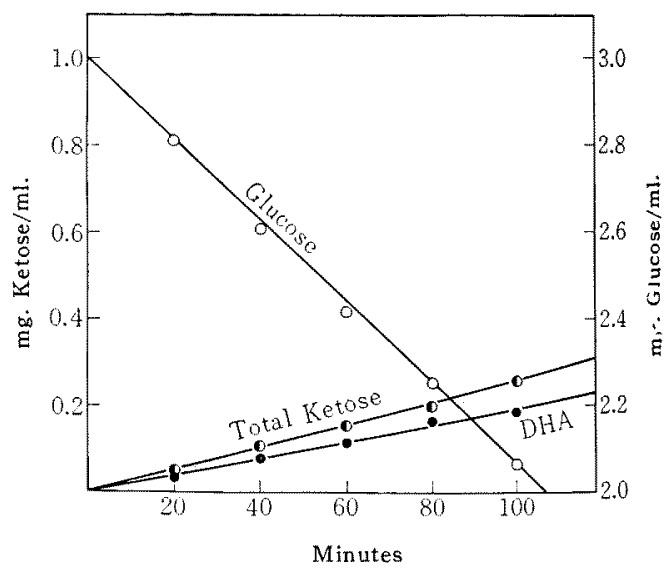

FIG. 1. Velocities of Glucose Disappearance and of Ketose Formation in the Course of Incubation using Resting-Cells.

The composition of the incubation mixture was $1.67 \times 10^{-2} \mathrm{M}$ of glucose, $1 \times 10^{-2} \mathrm{M}$ of Tris buffer, $\mathrm{pH} 8.0,7.7 \times 10^{-4} \mathrm{M}$ of $\mathrm{KH}_{2} \mathrm{PO}_{4}, 2 \times 10^{-4} \mathrm{M}$ of $\mathrm{MgSO}_{4}$, and $0.33 \mathrm{gm}$. (as dry welght) of resting cells in a total volume of $100 \mathrm{ml}$. 


\section{II) $\mathrm{pH}$ Estimation of Cytoplasmic Solution} Sixty-two $g$ of the washed cells were suspended in $268 \mathrm{ml}$ of distilled water (total volume of $325 \mathrm{ml})$, and exposed to a $10 \mathrm{kc}$ sonic oscillator $(100 \mathrm{~W})$ for thirty min. with complete distruction. After centrifugation, $100 \mathrm{ml}$ of the clarified sonicate was concentrated in vacuo at $30^{\circ} \mathrm{C}$ to $2.0 \mathrm{ml}$, measuring $\mathrm{pH}$ value at times. Taking into account that total intracellular volume of the cells resulting from $100 \mathrm{ml}$ of the sonicate was $1.56 \times 10^{3} \mathrm{~mm}^{3}$, a value of cytoplasmic $\mathrm{pH}$ was estimated as 6.35 by extrapolation to $1.56 \mathrm{ml}$ as described in Fig. 2.

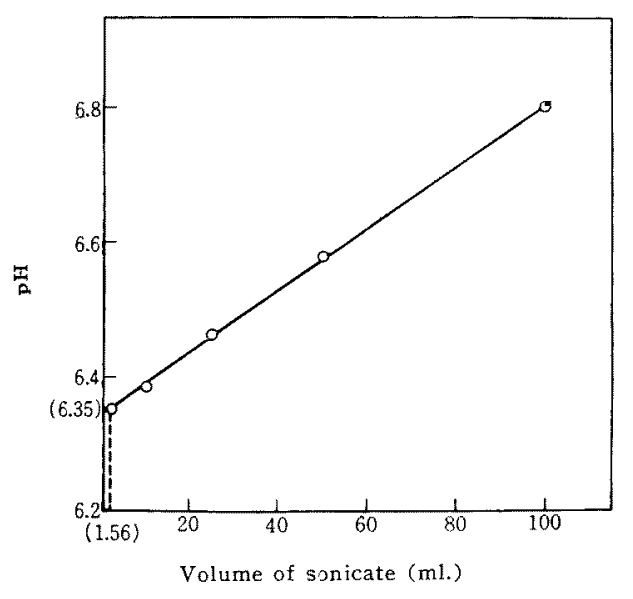

FIG. 2. pH Estimation of Cytoplasmic Solution.

Taking into account that the total intracellular volume of celis resulting from $100 \mathrm{ml}$. of the sonicate was $1.56 \times$ $10^{3} \mathrm{~mm}^{3}$, cytoplasmic $\mathrm{pH}$ was decided by extrapolation to the intracellular volume.

III) Enzymes Participating in the Initial Stage of Glucose Dissimilation The fact that glucose was in the highest level in the cells fermenting in a steady state ${ }^{2}$ led to the investigation of the relation between DHA-fermentation and intracellular activities of enzymes participating in the initial stage of glucose degradation.

a) Glucose Isomerase Activity in $\mathrm{Br}$. fuscum By employing the resting cells or the cell-free extract, it was confirmed that the cells, grown in the glucose medium, did not possess glucose isomerase catalyzing the following reaction;

$$
\text { D-Glucose } \longleftrightarrow^{\mathrm{D}} \text {-Fructose }
$$

b) Glucose Dehydrogenation Activity and its pH Dependence Fig. 3 shows a linear curve

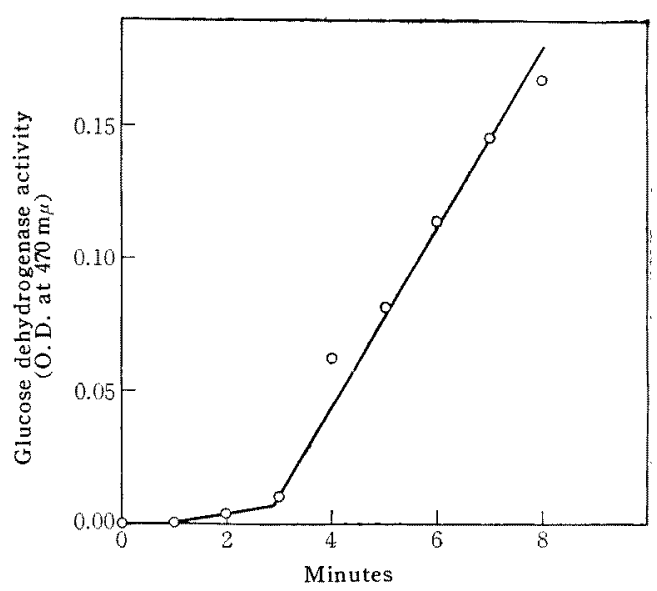

FIG. 3. Assay of Glucose Dehydrogenase Activity in $\mathrm{Br}$. fuscum.

The mixture initially contained $10 \mu$ moles of glucose, $75 \mu$ moles of Tris buffer, $1 \mu$ moles of TTC and $17.3 \mathrm{mg}$. (as. dry weight) of cells in a total volume of $3.0 \mathrm{ml}$.

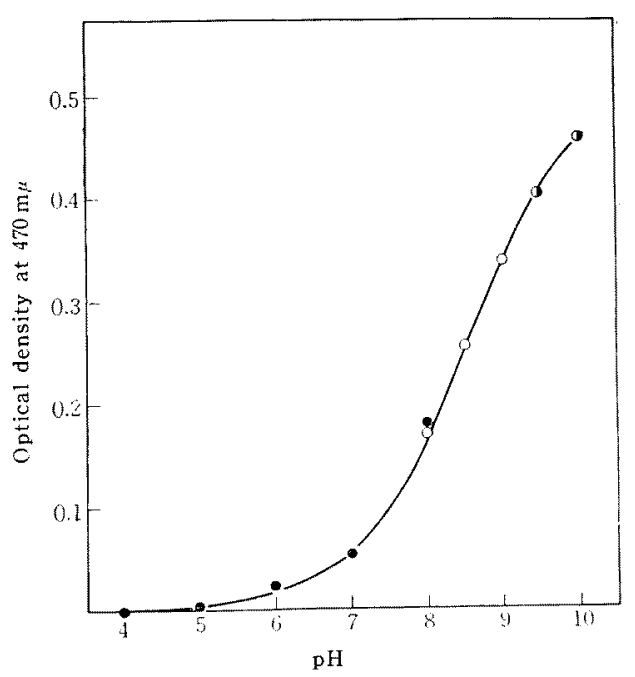

FIG. 4. Effect of $\mathrm{pH}$ on a Glucose Dehydrogenation. Incubation was carried out for 8 minutes at $22^{\circ} \mathrm{C}$. Con ${ }^{*}$ ditions are the same as in Fig. 3 except that the buffer was varied as indicated on the graph.

$-\mathrm{Na}_{2} \mathrm{HPO}_{4}$-Citric Acid

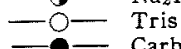

- Carbonate-Bicarbonate 
of glucose oxidation after a lag time of about three min. The lag time might be a time required for extracellular glucose to penetrate into the inside of the cells.

A test with the cell-free system might cause a disappearance of the lag time, but was not tested.

On the other hand, optimum $\mathrm{pH}$ of the reaction in this organism was found to be present above 10.0 as shown in Fig. 4.

Assuming that the cytoplasmic $\mathrm{pH}$ value is 6.35 , it appears rather doubtful that this enzymatic reaction occurs actively in vivo. This was confirmed by the following experiment.

c) Effect of Metals on the Glucose Dehydrogenation and Contribution of Glucose Dehydrogenase to DHA formation The effects of metallic ions upon glucose dehydrogenase activity were investigated by using the resting cells. The enzyme was inhibited completely by $\mathrm{Mn}^{++}, \mathrm{Co}^{++}, \mathrm{Ag}^{+}$and $\mathrm{Cu}^{++}$at the concentration of $2 \times 10^{-3} \mathrm{M}$. DHA production, however, was hardly affected by $\mathrm{Mn}^{++}$at the same concentration as outlined in Table I ( $\mathrm{a}$ and $\mathrm{b}$ ).

TABLE I. a) EFFECT OF METALS ON THE ACTIVITY of Glucose Dehydrogenase in Resting Cells

\begin{tabular}{|c|c|c|c|}
\hline Metal & $\begin{array}{l}\text { Final Con- } \\
\text { centration }\end{array}$ & $\begin{array}{l}\text { Optical Density } \\
\text { at } 470 \mathrm{~m} \mu\end{array}$ & $\begin{array}{l}\text { Residual } \\
\text { Activity }\end{array}$ \\
\hline $\mathrm{CaCl}_{2}$ & $1 \times 10^{-3} \mathrm{M}$ & .324 & $90 \%$ \\
\hline $\mathrm{BaCl}_{2}$ & $"$ & .350 & 97 \\
\hline $\mathrm{MgSO}_{4}$ & $" \prime$ & .354 & 99 \\
\hline $\mathrm{MnCl}_{2}$ & $"$ & .002 & 0 \\
\hline $\mathrm{ZnCl}_{2}$ & " & .354 & 99 \\
\hline $\mathrm{FeSO}_{4}$ & $"$ & .310 & 89 \\
\hline $\mathrm{FeCl}_{3}$ & " & .286 & 79 \\
\hline $\mathrm{CoCl}_{2}$ & $"$ & .000 & 0 \\
\hline $\mathrm{NiSO}_{4}$ & $" \prime$ & .348 & 97 \\
\hline $\mathrm{AgNO}_{3}$ & 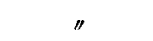 & .000 & 0 \\
\hline $\mathrm{CuCl}_{2}$ & " & .004 & 0 \\
\hline $\mathrm{HgCl}$ & $\mathrm{I} \times 10^{-4} \mathrm{M}$ & .328 & 91 \\
\hline None (Control) & & .360 & 100 \\
\hline
\end{tabular}

The assay mixture contained $10 \mu$ moles of D-glucose, 75

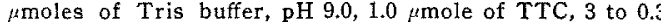
$\mu$ moles of respective metals and resting cells $(25 \mathrm{mg}$. as dry weight) in a final volume of $3.0 \mathrm{ml}$. Incubation was carried out for 5 minutes at $22^{\circ} \mathrm{C}$, after which the reaction was terminated by adding $2.0 \mathrm{ml}$. of $20 \%$ TCA The color was extracted with $5.0 \mathrm{ml}$. of ethylacetate, and then the absorption spectra at $470 \mathrm{~m} \mu$ were estimated.
TABle 1. b) Contribution of Glucose DeHYDROGENASE TO THE FOMATION OF DHA

$\begin{array}{ccccc}\text { Metal } & \mathrm{Mn}++ & \mathrm{Co}^{++} & \mathrm{Ag}^{+} & \mathrm{Cu}^{++} \\ & \mu \mathrm{g} . / \mathrm{ml} . & \mu \mathrm{g} . / \mathrm{ml} . & \mu \mathrm{g} . / \mathrm{ml} . & \mu \mathrm{g} . / \mathrm{ml} .\end{array}$

$\begin{array}{lllll}\text { DHA produced } & 181 & 139.5 & 94.7 & 13.8\end{array}$

The assay mixture contained $500 \mu$ moles of glucose, 250 $\mu$ moles of Tris buffer, $\mathrm{pH} 8.0,9.5 \mathrm{mg}$. of resting cells (as dry weight) and respective metals at the concentration of $2 \times 10^{-3} \mathrm{M}$. Incubation was carried out for $30 \mathrm{~min}$. at $30^{\circ} \mathrm{C}$, after which the reaction was terminated with $\mathrm{ZnSO}_{4}$ and $\mathrm{Ba}(\mathrm{OH})_{2}$, and then DHA in the aliquot was determined by the method of Dische and Borenfreund.

Only about $20 \%$ and $50 \%$ of the DHA producibility were inhibited by $\mathrm{Co}^{++}$and $\mathrm{Ag}^{+}$, respectively.

From these data, it was suggested that glucose dehydrogenation did not take part in DHA-formation in $\mathrm{Br}$. fuscum.

IV) Intracellular Levels of Materials Partici. pating in Glucokinase Reaction As previously described, the cytoplasmic concentration of materials concerning with glucokinase reaction in the steady state were estimated as $4.5 \times$ $10^{-2} \mathrm{M}$ for glucose, $2.01 \times 10^{-3} \mathrm{M}$ for ATP, $6.5 \times$ $10^{-3} \mathrm{M}$ for $\mathrm{ADP}, 5.6 \times 10^{-4} \mathrm{M}$ for $\mathrm{G} 6 \mathrm{P}$ and $4.81 \times 10^{-3}$ м for $\mathrm{Pi}^{2}{ }^{2}$

Furthermore, the following experiment was designed to determine the cytoplasmic level of $\mathrm{Mg}^{++}$Wet cells (10.2 g) was suspended in 5-fold volume of distilled water. The suspension was boiled for fifteen $\mathrm{min}$. and followed by centrifugation. The supernatant was removed and the entire cycle of this extaction was repeated once more with $60 \mathrm{ml}$ of distilled water. The supernatants were combined and hydrolyzed with $10 \mathrm{~N}_{2} \mathrm{H}_{2} \mathrm{SO}_{4}$. The hydrolyzate was percolated through the column of Dowex 1-X4 $\left(\mathrm{Cl}^{-}\right)$, and the effluent was concentrated to $50 \mathrm{ml}$.

For the analysis of $\mathrm{Ca}^{++}, 30 \mathrm{ml}$ of the concentrated fraction was neutralized and titrated with $0.0025 \mathrm{M}$ EDTA by using Dotite $\mathrm{NN}$ as indicator. The sum of $\mathrm{Ca}^{++}$and $\mathrm{Mg}^{++}$was analyzed with $0.01 \mathrm{M}$ EDTA by using Dotite $\mathrm{BT}$ as indicator.

Thus, the concentration of $\mathrm{Mg}^{++}$in the cytoplasm was calculated to be $6.29 \times 10^{-2} \mathrm{M}$. 
V) Intracellular Activity of Glucokinase and Participation of Glucokinase in Glucose Metabolism The above data indicated that pretty amounts of glucose and $\mathrm{Mg}^{++}$were present in the bacterial cells. But, in general, there are many cases in which enzymatic activities measured in vitro do not always coincide with their intracellular activities.

The same case was expected with glucokinase in $B r$. fuscum.

Total activity of glucokinase was estimated according to the method of Mizushima et al. ${ }^{10-14)}$ who had adopted it for the studies on glycolytic enzymes in Lactobacillus plantamim.

It was found that total activity of glucokinase extracted from $100 \mathrm{~g}$ of the cells (wet weight) of $\mathrm{Br}$. fuscum, was enough to phosphorylate $40.8 \mathrm{~g}$ of glucose per $\mathrm{hr}$. under the optimum conditions used. As illustrated in Table II, the intracellular activity of glucokinase was calculated to cause a phosphorylation of $3.042 \mathrm{~g}$ of glucose per hr. per $100 \mathrm{~g}$ of the cells (as wet weight), in consideration of intracellular levels of ATP, ADP, G6P, glucose, $\mathrm{pH}$, etc. This value may not be so widely different from the consumption velocity of extracellular glucose, if only a small experimental errors could be allowed. Thus, these observations appear to constitute at least

10) S. Mizushima, Y. Machida and K. Kitahara, J. Bacte riol, 86,1295 (1963).

11) S. Mizushima and K. Kitahara, ibid., 87, 1429 (1964).

12) S. Mizushima, T. Hiyama and K. Kitahara, J. Gen. Appl. Microbiol., 10, 33 (1964).

13) S. Mizushima and K. Kitahara, This Journal, 28, 339 (1964).

14) S. Mizushima and K. Kitahara, This Journal, 28, 344 (1964).
TABLE II. INTRACELlular CONCENTRATION of Materials Relating to GLUCOKINASE REACTION

Material Molar Concentration Calculated Factor for in the Cytoplasmic Glucokinse Activity

$\begin{array}{lll} & \text { Solution } \\ \text { ATP } & 2.01 \times 10^{-3} \mathrm{M} & 0.828\end{array}$

Glucose $\quad 4.5 \times 10^{-2} \mathrm{M} \quad 1.0$

ADP $\quad 6.5 \times 10^{-3} \mathrm{M} \quad(0.667$ (for ATP)

0.582 (for Glucose)

G6P $5.61 \times 10^{-4} \mathrm{M} \quad\left\{\begin{array}{l}0.546 \text { (for ATP) } \\ 0.695 \text { (for Glucose) }\end{array}\right.$

$\mathrm{Mg} \quad 6.29 \times 10^{-2} \mathrm{M} \quad 1.0$

$\mathrm{Pi} \quad 4.81 \times 10^{-3} \mathrm{M} \quad 1.0$

pH $\quad 6.35 \quad 0.627$

(total 0.0746 )

Intracellular Glucokinase Activity: $3.042 \mathrm{~g}$ of Glucose/hr./ $100 \mathrm{~g}$ of wet cells $(40.8 \times 0.0746)$

Extracellular Glucose Consumption Velocity: $3.965 \mathrm{~g}$ of Glucose $/ \mathrm{hr} . / 100 \mathrm{~g}$ of wet cells

suggestive evidence that the rate of glucose uptake in this organism is regulated by the rate of glucokinase reaction. There remains, however, the problem as to the cellular localization of the enzyme. Further studies on the metabolism of $\mathrm{Br}$. fuscum may provide the answer to this.

Acknowledgements The author wishes to express his sincerest gratitudes to Prof. K. Arima and Prof. Y. Ikeda of the University of Tokyo for their kind guidances throughout this work. Great indebtedness is also acknowledged to Dr. S. Mizushima for his valuable suggestions. The author also wishes to thank Dr. M. Mogi and Dr. N. Iguchi for their kind advices and encouragements. 